\title{
STUDIES ON THE VARIABILITY OF THE PRODUCTIVITY COMPONENTS IN A COLLECTION OF HOT PEPPER LANDRACES (CAPSICUM ANUUM VAR. MICROCARPUM)
}

\author{
Emilian Madoşă ${ }^{1}$, Lavinia Sasu ${ }^{2}$, Sorin Ciulca ${ }^{1}$, Constantin Avădanei ${ }^{1}$, Adriana Ciulca ${ }^{1}$, \\ Giancarla Velicevici ${ }^{1 *}$ \\ ${ }^{1}$ Banat's University of Agricultural Sceinces and Veterinary Medicine „King Michael I from \\ Romania” Timişoara, Calea Aradului 119, Timişoara, Romania \\ ${ }^{2}$ „Vasile Goldiş” Western University of Arad, B-dul Revolutiei 94, Arad, Romania
}

\begin{abstract}
The aim of the research was to evaluate the variability value of the main characters that contribute to the achievement of plant production to a collection of hot pepper genotypes. The biological material was composed of 17 landraces of hot peppers collected from western Romania. The study was conducted for two years, with biometric measurements on the morphological characteristics of fruit production on the plant. Intra-population variability was assessed (mean, standard deviation of mean and coefficient of variability) and differences between populations for these characters. The results show that the variability within the collection is high. Within populations, fruit sizes (length, diameter) are uniform, but the number of fruits and their weight per plant show greater variability. Within the collection, variations in morphological characteristics are large, especially for fruit length, fruit weight, number and weight of fruit per plant. Among the landraces studied, some may be recommended for breeding programs, as parents or as material for the application of selection: for long fruits (Juliţa, Aldeşti I and Satchinez I), for short fruits (Satchinez III), but also the landraces Rieni III (17.07 g average weight of the fruit), Temerești II (89.82 fruits per plant), Aldești I (931.17 g fruits per plant).
\end{abstract}

Keywords: hot pepper, morphological characters, variability

\section{INTRODUCTION}

The concerns about the use of local germplasm in vegetables are widespread worldwide. The collection of local germplasm from pepper varieties also took place in western Romania. The purpose of these collections was to save the landraces and their use in breeding programs (Madosa et al., 2008; Madosa et al., 2010).

The great diversity existing to pepper, and in particular for hot peppers, is due to the cultivation of several species with hot fruits, but also the fact that thie origin is from different centers. The domestication and selection played a very important role in diversification. (Pereira-Dias et al., 2019)

The importance of hot peppers is not only for fresh fruit consumption, but also from a medicinal point of view. The fruits have good nutritional value, bringing benefits to the health of the consumer. To improve these characteristics, the germplasm processing by traditional selection or cross-breeding, it must lead to the specialization of new varieties for certain modes of use (Kuhn et al., 2016). 
The variability of hot peppers is high in the species Capsicum annuum, but also in other cultivated species, or in wild species of the genus Capsicum. The differentiation of varieties and species can be made according to the morphological characters, but highlighting genetic differences is possible with the help of molecular markers. This method should also be used for local germplasm. For hot peppers, the most important thing would be to highlight the genes that determine the content of capsicin (Ramchiary et al., 2013).

The tradition of cultivating a population in a certain region must be encouraged. Many farmers are oriented towards replacing the landraces with foreign varieties. Often, in such cases the quality of production is lower. To maintain the local germplasm should be assessed and processed to increase the performances productive (Munoz-Concha et al., 2020).

The morphological characterization is recommended for characters with quantitative determinism, these being more unstable, depending on the environmental conditions. It is recommended to observe as many characters as possible. A narrow genetic base can lead to the loss of components that can affect productivity (Birhanu et al., 2017).

The characterization of the variability must be done also by observing some characters that, apparently not related to productive potential. Along with the size and weight of the fruit, the height of the plant, the number of branches per plant or leaf area are also important (Meena et al., 2016).

Other studies have concluded that the vegetative development of the plant has a direct influence on productivity (Orobiyi et al., 2017).

For morphological characterize of fruits, the determining thier size is very important. But, the evolution of these dimensions over time is also important, in correaltion with the technological conditions. Some researchers recommend measuring the length and diameter of the fruit twice a week. Such measurements may be included in computer systems, establishing functions of correlation between size and weight of fresh fruit and accumulation of dry matter. Such functions can be used in estimating yields and determining the optimum time to harvest (Maaike et al., 2012). The evaluation is done by observing the diversity of a large number of morphological characteristics, including the observation of tolerance against attack by diseases. Fruit production, the main selective character, can vary within very wide limits for hot peppers. There are mentioned limits of variation from 0.8 to $4.5 \mathrm{t} /$ ha. Each character of the fruit participates in the production: the average weight of the fruit, the thickness of the pericarp of the fruit, the diameter and length of the fruit. Some of these characters have a high heritability (average fruit weight, fruit length, fruit diameter), by selecting according to their values, it is possible to improve the level of yields per unit area (Fasikaw et al., 2020)

The germplasm collections are sources for genetic progress in breeding programs. The interest in them has increased recently due to the use of molecular markers. By studying of some materials from 89 countries, it was found that the genetic structure of cultivated peppers was severely affected by the long-term artificial selection of populations in primary centers, but also in secondary diversification centers. As a result, regardless of where a landrace is formed, it may contain unknown and useful genes (Marysevet al., 2013).

To use the local germplasm correctly, in addition to assessing the variability are necessary studies on heritability and correlations between these characters. Through a complex overview of the material, the genetic progress achieved through selection can be much greater and the creating highperformance forms can be done faster (Shimeles et al., 2016).

The experimentation in multiple ecological locations of pepper germplasm showed a major involvement of environmental conditions in achieving plant productivity, although the main effects 
of genetic determination are those of additivity. The interpretation of the results regarding the manifestation of morphological characters must be made in correlation with the climatic conditions. (Derek et al., 2018).

Studies on a large number of peppers provenances from China, using molecular markers, they pointed out that the genetic structure of populations is linked to their geographical origin. Such differences have been reported for several characters used as fruit descriptors. Diversity has also been stimulated by the migration of genotypes, but also by human selection made according to consumption patterns and adaptation to very diverse climatic conditions (Zhang Xiao-min et al., 2016).

The modern methods of assessing variability using molecular markers provide good genetic characterization, but there are many situations when there is no close association between molecular markers and phenotypic traits. For this reason, the two methods must be applied together, phenotypic determinations having of particular importance (Leonel et al., 2020).

\section{MATERIALS AND METHODS}

The research aimed to study a collection consisting of hot peppers landraces, in terms of the manifestation of the characters that contribute to the production of fruit on the plant. Was organized a collection field, on plots that included 100 plants each. The experiment was performed for two years. The applied technology was similar to that practiced in traditional cropping systems, with moderate fertilization, without irrigation. The biological material included landraces collected from western of Romania, which were studied compared to the old variety Portocaliu, variety created in the same region. The observations were made by biometric measurements on samples of representative plants. Were taken into account the morphological characteristics that characterize the production potential of a plant. The experimental data were statistically processed, being determined the mean $(\mathrm{x})$, the standard deviation of the mean $\left(\mathrm{s}_{\mathrm{x}}\right)$, the coefficient of variability $(\mathrm{s} \%)$. Were also performed the analysis of variance and were application the $t$ test (Ciulca, 2006).

\section{RESULTS AND DISCUSSIONS}

In the hot pepper studied, in the first year of study, the variability remained high for some characters, although before the start of the experiment, a selection was applied for homogenize the collected landraces.

The length of the fruits was very varied, the minimum value being $3.64 \mathrm{~cm}$ for the population of Satchinez III and $19.12 \mathrm{~cm}$ for the population of Juliţa. The diameters of the fruits did not vary as much as the length. The variability limits were between $0.89 \mathrm{~cm}$ in the Temereşti II population and $2.28 \mathrm{~cm}$ in the Rieni III population. Depending on these sizes, the average weight of the fruit also varied. The lightest fruits were presented by the population whose fruits were the thinnest, Temerești II with an weight average of $3.72 \mathrm{~g}$. The heaviest fruits were reported in the population of Aldeşti I (17.74 g). Quite large variations were also present for the number of fruits per plant (25.75 fruits for the Portocaliu variety, 128.5 fruits for the population of Temeresti II). The limits of the interpopulation variability interval for the weight of the fruit on the plant were $235.82 \mathrm{~g}$ (Temereşti I) and $1510.73 \mathrm{~g}$ (Aldeşti I population). The comparing of populations with the control variety is difficult to do, because in hot peppers the diversity for the size and shape of the fruit is great. Of course, the production per plant, through the economic effect it produces is an important element (Table 1 and 2). 


\section{Current Trends in Natural Sciences}

Vol. 10, Issue 19, pp. 201-208, 2021

https://doi.org/10.47068/ctns.2021.v10i19.027

Current Trends in Natural Sciences (on-line)

In the second year of experimentation, in some populations the variability was reduced, because the selection was continued.

Table 1. Results regarding the variability of the morphological characters of the fruits

\begin{tabular}{|c|c|c|c|c|c|c|c|}
\hline \multirow[t]{2}{*}{ No } & \multirow[t]{2}{*}{ Genotype } & \multicolumn{2}{|c|}{$\begin{array}{c}\text { Fruit length }(\mathrm{cm}) \\
\mathrm{x} \pm \mathrm{S}_{\mathrm{x}} \\
\mathrm{S} \%\end{array}$} & \multicolumn{2}{|c|}{$\begin{array}{c}\text { Fruit diameter }(\mathrm{cm}) \\
\mathrm{x} \pm \mathrm{S} \mathrm{x} \\
\mathrm{S} \%\end{array}$} & \multicolumn{2}{|c|}{$\begin{array}{c}\text { Fruit weight }(\mathrm{cm}) \\
\qquad \pm \mathrm{s}_{\mathrm{x}} \\
\mathrm{S} \%\end{array}$} \\
\hline & & 2018 year & 2019 year & 2018 year & 2019 year & 2018 year & 2019 year \\
\hline 1. & $\begin{array}{c}\text { Portocaliu } \\
\text { (control) }\end{array}$ & $\begin{array}{c}7.90 \pm 0.27 \\
6.98 \\
\end{array}$ & $\begin{array}{c}5.51 \pm 0.48 \\
8.84\end{array}$ & $\begin{array}{c}1.94 \pm 0.05 \\
5.52\end{array}$ & $\begin{array}{c}1.80 \pm 0.28 \\
15.71\end{array}$ & $\begin{array}{c}13.64 \pm 0.64 \\
9.38\end{array}$ & $\begin{array}{c}8.87 \pm 2.90 \\
32.79\end{array}$ \\
\hline 2. & Temereşti I & $\begin{array}{c}6.80 \pm 0.87 \\
31.60\end{array}$ & $\begin{array}{c}4.26 \pm 0.29 \\
6.94\end{array}$ & $\begin{array}{c}1.16 \pm 0.16 \\
35.66\end{array}$ & $\begin{array}{c}1.10 \pm 0.08 \\
7.75\end{array}$ & $\begin{array}{c}3.18 \pm 0.64 \\
35.93\end{array}$ & $\begin{array}{c}2.46 \pm 0.66 \\
26.99\end{array}$ \\
\hline 3. & Temereşti II & $\begin{array}{c}9.52 \pm 0.38 \\
8.16\end{array}$ & $\begin{array}{c}7.12 \pm 0.62 \\
8.75\end{array}$ & $\begin{array}{c}0.89 \pm 0.02 \\
6.36\end{array}$ & $\begin{array}{c}0.75 \pm 0.07 \\
9.61\end{array}$ & $\begin{array}{c}3.72 \pm 0.29 \\
16.02\end{array}$ & $\begin{array}{c}2.34 \pm 0.67 \\
28.62\end{array}$ \\
\hline 4. & Temereşti III & $\begin{array}{c}6.48 \pm 0.27 \\
11.86 \\
\end{array}$ & $\begin{array}{c}6.26 \pm 0.56 \\
9.03\end{array}$ & $\begin{array}{c}1.12 \pm 0.03 \\
9.40 \\
\end{array}$ & $\begin{array}{c}1.03 \pm 0.05 \\
4.98 \\
\end{array}$ & $\begin{array}{c}4.04 \pm 0.33 \\
23.65 \\
\end{array}$ & $\begin{array}{c}3.57 \pm 0.59 \\
16.58 \\
\end{array}$ \\
\hline 5. & Satchinez I & $\begin{array}{c}14.31 \pm 0.64 \\
10.12\end{array}$ & $\begin{array}{c}14.92 \pm 1.94 \\
13.02\end{array}$ & $\begin{array}{c}1.05 \pm 0.04 \\
9.13\end{array}$ & $\begin{array}{c}0.81 \pm 0.06 \\
8.47\end{array}$ & $\begin{array}{c}6.03 \pm 0.59 \\
21.87\end{array}$ & $\begin{array}{c}6.67 \pm 1.37 \\
20.54\end{array}$ \\
\hline 6. & Satchinez II & $\begin{array}{c}9.10 \pm 0.72 \\
19.63\end{array}$ & $\begin{array}{c}7.25 \pm 1.24 \\
17.21\end{array}$ & $\begin{array}{c}1.31 \pm 0.06 \\
12.04\end{array}$ & $\begin{array}{c}1.52 \pm 0.13 \\
8.55\end{array}$ & $\begin{array}{c}6.34 \pm 0.70 \\
27.38\end{array}$ & $\begin{array}{c}5.77 \pm 1.60 \\
27.71\end{array}$ \\
\hline 7. & Satchinez III & $\begin{array}{c}3.64+60.13 \\
9.54\end{array}$ & $\begin{array}{c}1.98 \pm 0.36 \\
18.52\end{array}$ & $\begin{array}{c}2.04 \pm 0.04 \\
5.36\end{array}$ & $\begin{array}{c}1.86 \pm 0.23 \\
12.48\end{array}$ & $\begin{array}{c}8.18 \pm 0.65 \\
21.23\end{array}$ & $\begin{array}{c}3.55 \pm 0.99 \\
28.03\end{array}$ \\
\hline 8. & Satchinez IV & $\begin{array}{c}8.55 \pm 0.30 \\
8.85 \\
\end{array}$ & $\begin{array}{c}2.31 \pm 1.36 \\
11.10\end{array}$ & $\begin{array}{c}1.04 \pm 0.03 \\
7.70\end{array}$ & $\begin{array}{c}1.10 \pm 0.13 \\
12.19\end{array}$ & $\begin{array}{c}4.01 \pm 0.22 \\
13.98\end{array}$ & $\begin{array}{c}7.48 \pm 1.77 \\
23.72\end{array}$ \\
\hline 9. & Aldeşti I & $\begin{array}{c}17.91 \pm 0,69 \\
9.54\end{array}$ & $\begin{array}{c}13.01 \pm 1.55 \\
11.91\end{array}$ & $\begin{array}{c}1.65 \pm 0.06 \\
9.76\end{array}$ & $\begin{array}{c}1.81 \pm 0.17 \\
9.90\end{array}$ & $\begin{array}{c}17.74 \pm 0.83 \\
11.47 \\
\end{array}$ & $\begin{array}{c}14.83 \pm 2.66 \\
17.98 \\
\end{array}$ \\
\hline 10. & Aldeşti II & $\begin{array}{c}5.92 \pm 0.17 \\
6.71 \\
\end{array}$ & $\begin{array}{c}4.81 \pm 0.74 \\
15.93 \\
\end{array}$ & $\begin{array}{c}2.13 \pm .0 .12 \\
12.78 \\
\end{array}$ & $\begin{array}{c}1.94 \pm 0.21 \\
10.94\end{array}$ & $\begin{array}{c}8.60 \pm 0.12 \\
3.20 \\
\end{array}$ & $\begin{array}{c}7.85 \pm 1.33 \\
16.95 \\
\end{array}$ \\
\hline 11. & Rieni I & $\begin{array}{c}7.29 \pm 0.97 \\
23.22 \\
\end{array}$ & $\begin{array}{c}6.64 \pm 0.52 \\
7.91 \\
\end{array}$ & $\begin{array}{c}1.88 \pm 0.13 \\
12.72 \\
\end{array}$ & $\begin{array}{c}1.57 \pm 0.08 \\
5.24\end{array}$ & $\begin{array}{c}8.43 \pm 2.63 \\
54.13 \\
\end{array}$ & $\begin{array}{c}7.78 \pm 0.97 \\
12.50 \\
\end{array}$ \\
\hline 12. & Rieni II & $\begin{array}{c}5.03 \pm 0.28 \\
15.08\end{array}$ & $\begin{array}{c}4.61 \pm 0.24 \\
5.35\end{array}$ & $\begin{array}{c}1.91 \pm 0.04 \\
5.72\end{array}$ & $\begin{array}{c}2.01 \pm 0.16 \\
8.27\end{array}$ & $\begin{array}{c}7.39 \pm 0.33 \\
11.96\end{array}$ & $\begin{array}{c}7.06 \pm 0.69 \\
9.85\end{array}$ \\
\hline 13. & Rieni III & $\begin{array}{c}10.71 \pm 2.36 \\
31.21\end{array}$ & $\begin{array}{c}9.85 \pm 0.65 \\
6.64\end{array}$ & $\begin{array}{c}2.28 \pm 0.22 \\
13.64\end{array}$ & $\begin{array}{c}2.32 \pm 0.12 \\
5.38\end{array}$ & $\begin{array}{c}17.17 \pm 5.42 \\
44.64\end{array}$ & $\begin{array}{c}16.97 \pm 2.23 \\
13.19\end{array}$ \\
\hline 14. & Apateu I & $\begin{array}{c}8.97 \pm 1.53 \\
29.66 \\
\end{array}$ & $\begin{array}{c}12.76 \pm 1.65 \\
12.96\end{array}$ & $\begin{array}{c}1.86 \pm 0.11 \\
10.24 \\
\end{array}$ & $\begin{array}{c}1.66 \pm 0.29 \\
17.88 \\
\end{array}$ & $\begin{array}{c}13.45 \pm 3.22 \\
41.46 \\
\end{array}$ & $\begin{array}{c}13.71 \pm 3.06 \\
22.33\end{array}$ \\
\hline 15. & Apateu II & $\begin{array}{c}12.40 \pm 0.27 \\
4.97\end{array}$ & $\begin{array}{c}8.70 \pm 1.29 \\
14.86\end{array}$ & $\begin{array}{c}1.20 \pm 0.04 \\
8.00\end{array}$ & $\begin{array}{c}1,77 \pm 0.16 \\
9.05\end{array}$ & $\begin{array}{c}8.74 \pm 0.20 \\
23.21\end{array}$ & $\begin{array}{c}12.88 \pm 3.05 \\
23.71\end{array}$ \\
\hline 16. & Pădureni & $\begin{array}{c}11.98 \pm 0.87 \\
3.89\end{array}$ & $\begin{array}{c}11.36 \pm 1.72 \\
15.16\end{array}$ & $\begin{array}{c}2.10 \pm 0.11 \\
10.26\end{array}$ & $\begin{array}{c}1.33 \pm 0.15 \\
11.25\end{array}$ & $\begin{array}{c}9.06 \pm 2.88 \\
24.11\end{array}$ & $\begin{array}{c}9.86 \pm 2.34 \\
23.76\end{array}$ \\
\hline 17. & Secusigiu & $\begin{array}{c}12.45 \pm 10.64 \\
11.64 \\
\end{array}$ & $\begin{array}{c}10.71 \pm 1.26 \\
11.79\end{array}$ & $\begin{array}{c}1.38 \pm 0.07 \\
12.35 \\
\end{array}$ & $\begin{array}{c}1.30 \pm 0.11 \\
8.88 \\
\end{array}$ & $\begin{array}{c}9.32 \pm 1.25 \\
30.01\end{array}$ & $\begin{array}{c}8.49 \pm 2.52 \\
29.68\end{array}$ \\
\hline 18. & Juliţa & $\begin{array}{c}19.12 \pm 1.44 \\
12.21\end{array}$ & $\begin{array}{c}17.15 \pm 1.44 \\
8.44\end{array}$ & $\begin{array}{c}1.23 \pm 0.03 \\
8.53\end{array}$ & $\begin{array}{c}1.20 \pm 0.06 \\
5.02\end{array}$ & $\begin{array}{c}13.32 \pm 0.95 \\
20.18\end{array}$ & $\begin{array}{c}10.59 \pm 1.52 \\
14.40\end{array}$ \\
\hline
\end{tabular}

The length of the fruit is the character with the greatest variability. Interpopulatively, the range of variability was between $1.98 \mathrm{~cm}$ in the Satchinez III population and $17.15 \mathrm{~cm}$ in the Juliţa population. The variability within populations for fruit length has been reduced. The diameter of the fruits showed a lower variability within the collection. In general, the fruits are thin. The average values recorded were $0.75 \mathrm{~cm}$ in the population of Temerești II and $2.32 \mathrm{~cm}$ in the population of Rieni III. Intrapopulational, the variability of fruit diameter is reduced. The average of fruits weight being between $2.34 \mathrm{~g}$ in the population of Temereşti II and $14.83 \mathrm{~g}$ in the population of Aldeşti I. The variability of fruit weight in populations is medium to large, the fruit being quite uneven in weight. And the number of fruits per plant had great variability. The fewest fruits were presented by 


\section{Current Trends in Natural Sciences}

Vol. 10, Issue 19, pp. 201-208, 2021

https://doi.org/10.47068/ctns.2021.v10i19.027

Current Trends in Natural Sciences (on-line)

the control variety Orange (12.87 fruits), this being a genotype with determined growth, the landraces have been fruitful for a longer period of time or almost continuously. Thus, in the population of Temerești II, the number of fruits per plant reached an average of 51.96 fruits in autumn. Within the populations the variability was medium or high. The weight of the fruits per plant showed very different values in the collection depending on the number and especially the size of the fruits. The lowest production per plant was made in the population of Satchinez III $(84.66 \mathrm{~g})$, and the highest in the population of Apateu II $(566.84 \mathrm{~g})$. The coefficients of variability for this character were high, revealing a great variability. (Table 1 and 2)

Table 2. Results regarding the variability of fruit weight after drying

\begin{tabular}{|c|c|c|c|c|c|}
\hline \multirow[t]{2}{*}{ No } & \multirow[t]{2}{*}{ Genotype } & \multicolumn{2}{|c|}{$\begin{array}{c}\text { Fruits number per plant } \\
\mathrm{x} \pm \mathrm{s}_{\mathrm{x}} \\
\mathrm{S} \%\end{array}$} & \multicolumn{2}{|c|}{$\begin{array}{c}\text { Fruits weight per plant }(\mathrm{g}) \\
\mathrm{x} \pm \mathrm{s}_{\mathrm{x}} \\
\mathrm{S} \%\end{array}$} \\
\hline & & 2018 year & 2019 year & 2018 year & 2019 year \\
\hline 1. & $\begin{array}{c}\text { Portocaliu } \\
\text { (control) }\end{array}$ & $\begin{array}{c}25.75 \pm 2.01 \\
15.65\end{array}$ & $\begin{array}{c}12.87 \pm 1.70 \\
37.46\end{array}$ & $\begin{array}{c}351.23 \pm 44.83 \\
51,69\end{array}$ & $\begin{array}{c}114.15 \pm 20.44 \\
56.15\end{array}$ \\
\hline 2. & Temereşti I & $\begin{array}{c}74.16 \pm 14.57 \\
48.14\end{array}$ & $\begin{array}{c}35.66 \pm 7.08 \\
59.60\end{array}$ & $\begin{array}{c}235.82 \pm 43.05 \\
43.12\end{array}$ & $\begin{array}{c}87.72 \pm 16.31 \\
61.22\end{array}$ \\
\hline 3. & Temereşti II & $\begin{array}{c}128.25 \pm 25.77 \\
40.20\end{array}$ & $\begin{array}{c}51.40 \pm 4.31 \\
26.55\end{array}$ & $\begin{array}{c}477.09 \pm 42.09 \\
24.66\end{array}$ & $\begin{array}{c}120.27 \pm 8.36 \\
28.94\end{array}$ \\
\hline 4. & Temereşti III & $\begin{array}{c}88.26 \pm 18.16 \\
58.20\end{array}$ & $\begin{array}{c}36.62 \pm 3.17 \\
24.54\end{array}$ & $\begin{array}{c}356.57 \pm 52.17 \\
46.53\end{array}$ & $\begin{array}{c}130.73 \pm 10.57 \\
35.62\end{array}$ \\
\hline 5. & Satchinez I & $\begin{array}{c}101.40 \pm 37.25 \\
82.15\end{array}$ & $\begin{array}{c}22.22 \pm 4.73 \\
63.86\end{array}$ & $\begin{array}{c}611.44 \pm 67.57 \\
50.88\end{array}$ & $\begin{array}{c}148.20 \pm 19.77 \\
86.51\end{array}$ \\
\hline 6. & Satchinez II & $\begin{array}{c}70.50 \pm 10.35 \\
35.98\end{array}$ & $\begin{array}{c}27.62 \pm 3.17 \\
32.54\end{array}$ & $\begin{array}{c}446.97 \pm 33.37 \\
26.44\end{array}$ & $\begin{array}{c}159.36 \pm 24.18 \\
53.32\end{array}$ \\
\hline 7. & Satchinez III & $\begin{array}{c}61.14 \pm 8.11 \\
35.09 \\
\end{array}$ & $\begin{array}{c}23.85 \pm 3.66 \\
40.59\end{array}$ & $\begin{array}{c}500.12 \pm 54.77 \\
41.95 \\
\end{array}$ & $\begin{array}{c}84.66 \pm 11.75 \\
59.84 \\
\end{array}$ \\
\hline 8. & Satchinez IV & $\begin{array}{c}84.16 \pm 15.21 \\
44.28\end{array}$ & $\begin{array}{c}29.62 \pm 3.64 \\
34.84\end{array}$ & $\begin{array}{c}337.48 \pm 36.27 \\
37.22\end{array}$ & $\begin{array}{c}221.55 \pm 23.06 \\
43.59\end{array}$ \\
\hline 9. & Aldeşti I & $\begin{array}{c}85.16 \pm 3.53 \\
33.96\end{array}$ & $\begin{array}{c}23.71 \pm 5.85 \\
65.31\end{array}$ & $\begin{array}{c}1510.73 \pm 23.03 \\
24.43\end{array}$ & $\begin{array}{c}351.61 \pm 69.22 \\
67.84\end{array}$ \\
\hline 10. & Aldeşti II & $\begin{array}{c}75.00 \pm 10.84 \\
32.33 \\
\end{array}$ & $\begin{array}{c}36.25 \pm 6.65 \\
44.15 \\
\end{array}$ & $\begin{array}{c}645.00 \pm 66.87 \\
29.18 \\
\end{array}$ & $\begin{array}{c}284.56 \pm 38.38 \\
44.77 \\
\end{array}$ \\
\hline 11. & Rieni I & $\begin{array}{c}38.00 \pm 19.13 \\
87.23\end{array}$ & $\begin{array}{c}44.12 \pm 6.06 \\
38.84\end{array}$ & $\begin{array}{c}320.34 \pm 159.93 \\
96.56\end{array}$ & $\begin{array}{c}343.25 \pm 31.06 \\
37.02\end{array}$ \\
\hline 12. & Rieni II & $\begin{array}{c}47.71 \pm 8.47 \\
47.01\end{array}$ & $\begin{array}{c}31.85 \pm 7.36 \\
61.17\end{array}$ & $\begin{array}{c}352.57 \pm 59.77 \\
55.98\end{array}$ & $\begin{array}{c}224.86 \pm 63.77 \\
86.96\end{array}$ \\
\hline 13. & Rieni III & $\begin{array}{c}42.00 \pm 6.00 \\
20.20\end{array}$ & $\begin{array}{c}18.60 \pm 4.11 \\
49.50\end{array}$ & $\begin{array}{c}721.14 \pm 63.00 \\
20.85\end{array}$ & $\begin{array}{c}315.64 \pm 62.93 \\
52.16\end{array}$ \\
\hline 14. & Apateu I & $\begin{array}{c}39.70 \pm 22.04 \\
96.10 \\
\end{array}$ & $\begin{array}{c}17.80 \pm 2.26 \\
28.48\end{array}$ & $\begin{array}{c}533.96 \pm 106.15 \\
46.25 \\
\end{array}$ & $\begin{array}{c}244.03 \pm 44.93 \\
75.26 \\
\end{array}$ \\
\hline 15. & Apateu II & $\begin{array}{c}50.20 \pm 4.78 \\
21.33\end{array}$ & $\begin{array}{c}44.01 \pm 5.32 \\
36.25\end{array}$ & $\begin{array}{c}438.74 \pm 38.83 \\
28.98 \\
\end{array}$ & $\begin{array}{c}566.84 \pm 96.35 \\
49.36\end{array}$ \\
\hline 16. & Pădureni & $\begin{array}{c}46.21 \pm 8.97 \\
68.91\end{array}$ & $\begin{array}{c}29.83 \pm 7.33 \\
60.23 \\
\end{array}$ & $\begin{array}{c}418.66 \pm 53.41 \\
51.23 \\
\end{array}$ & $\begin{array}{c}294.12 \pm 46.42 \\
51.49 \\
\end{array}$ \\
\hline 17. & Secusigiu & $\begin{array}{c}29.37 \pm 5.41 \\
31.85\end{array}$ & $\begin{array}{c}28.06 \pm 5.55 \\
43.43\end{array}$ & $\begin{array}{c}273.72 \pm 51.24 \\
41.85\end{array}$ & $\begin{array}{c}238.22 \pm 43.46 \\
49.28\end{array}$ \\
\hline 18. & Juliţa & $\begin{array}{c}27.75 \pm 3.11 \\
31.75\end{array}$ & $\begin{array}{c}33.42 \pm 7.00 \\
55.42\end{array}$ & $\begin{array}{c}369.63 \pm 34.65 \\
35.84\end{array}$ & $\begin{array}{c}353.91 \pm 95.85 \\
65.85\end{array}$ \\
\hline
\end{tabular}

The statistical processing on the experimental cycle highlights the differences between the landraces and the control variety. 
The averages of the experimental years can highlight the most valuable populations from a productive point of view. For the average weight of the fruit, the comments are difficult to make because the variability in the collection is very high. Many consumers prefer smaller fruits, especially if they are very spicy. Among the studied landraces, nine have lighter fruits with statistically assured differences from the control. The only population with larger fruits was Rieni III. The existing variability within the population makes it valuable for the amelioration process, useful for the amelioration process being both the populations with small fruits and those with large fruits. (Table 3.) The number of fruits per plant is the most important character for the productive potential. According to the averages of this character, the populations in the collection are superior to the control. None of the populations showed negative differences compared to the Portocaliu variety. The most productive plants were presented by the population of Temereşti II. The populations Temeresti III, Satchinez I and Satchinez IV also showed very significant increases. Differences statistically ensured compared to the control were also recorded populations: Temereşti I, Satchinez II, Aldeşti I, Aldeşti II, Apateu II. This situation gives value to the collection, the populations having a very good productive potential. This may be due to the fact that in the Portocaliu variety, the formation of fruits is limited, towards autumn the plant stops growing and fruiting. The landraces vegetate continuously, until the first frosts appear. (Table 3.)

The number of fruits per plant is dependent on climatic conditions by fertilizing the flowers and reaching their harvest maturity. Some researches mention that there are situations when only $18.81 \%$ of flowers produce fruit, and of the fruits formed, $72.41 \%$ reach harvest maturity. Thus, the total number of fruits per plant varied from 6 to 71, the production also varying from 7.97 to 95.33 q / ha (Dahal et al., 2015).

The element of productivity with economic effect is the production of fruits per plant. In the case of hot peppers, the randament per plant achieved were not as different as the size of the fruits or their number. There was also great variability for plant habitus. Forms with small fruits and in large numbers showed more vigorous plants, and in those with large fruits, the plants had a lower vigor. Thus, the production per plant varied from $161.77 \mathrm{~g}$ for the population of Temereşti I, to $931.17 \mathrm{~g}$ for the population of Aldeşti I. Compared to the Portocaliu variety used as a control, , no were reported populations with lower plant yields with statistical assurance. However, there are populations with fruit weight per plant higher than the one made by the control, in which the differences are ensured statistically very significant (Aldeşti I) or significant (Aldeşti II, Rieni III, Apateu II) (Table 3.)

The number of fruits per plant, the length of the fruit, the width of the fruit, the number of seeds per fruit are correlated with each other and are influenced by the interaction of the genotype with planting distances. Therefore, even in the case of lamndraces, cultivated in the areas of origin according to different technologies, the technology can influence the manifestation of production characters. (Abdul-Rafiu et.al., 2019). 
Current Trends in Natural Sciences

Vol. 10, Issue 19, pp. 201-208, 2021

https://doi.org/10.47068/ctns.2021.v10i19.027

Current Trends in Natural Sciences (on-line)

ISSN: 2284-953X

Current Trends in Natural Sciences (CD-Rom)

ISSN: 2284-9521

ISSN-L: 2284-9521

ISSN-L: 2284-9521

Table 3. Results regarding the manifestation of the component characters of the production on the plant

\begin{tabular}{|c|c|c|c|c|c|c|c|c|c|c|}
\hline \multirow[t]{2}{*}{ No } & \multirow[t]{2}{*}{ Genotype } & \multicolumn{3}{|c|}{ Fruit weight $(\mathrm{g})$} & \multicolumn{3}{|c|}{ Fruits number per plant } & \multicolumn{3}{|c|}{ Fruits weight per plant $(\mathrm{g})$} \\
\hline & & $\begin{array}{c}\text { Averag } \\
\text { e }\end{array}$ & $\begin{array}{c}\text { Percentage } \\
\text { of control } \\
(\%)\end{array}$ & $\begin{array}{l}\text { Difference } \\
\text { from } \\
\text { control/ } \\
\text { significance }\end{array}$ & Average & $\begin{array}{l}\text { Percentage } \\
\text { of control } \\
(\%)\end{array}$ & $\begin{array}{l}\text { Difference } \\
\text { from } \\
\text { control/ } \\
\text { significanc } \\
\mathrm{e}\end{array}$ & Average & $\begin{array}{l}\text { Percentag } \\
\text { e of } \\
\text { control } \\
(\%)\end{array}$ & $\begin{array}{l}\text { Differenc } \\
\text { e from } \\
\text { control/ } \\
\text { significan } \\
\text { ce }\end{array}$ \\
\hline 1. & $\begin{array}{l}\text { Portocaliu } \\
\text { (mt) }\end{array}$ & 11.25 & 100 & Mt & 19.26 & 100 & Mt & 232.69 & 100.00 & Mt. \\
\hline 2. & Temereşti I & 2.82 & 25.05 & $-8.43^{000}$ & 54.91 & 285.02 & $35.64 * *$ & 161.77 & 69.52 & -70.92 \\
\hline 3. & Temereşti II & 3.03 & 26.92 & $-8.22^{000}$ & 89.82 & 466.26 & $70.56 * * *$ & 298.68 & 128.35 & 65.99 \\
\hline 4. & Temereşti III & 3.80 & 33.80 & $-7.45^{000}$ & 62.44 & 324.11 & $43.17 * * *$ & 243.65 & 104.71 & 10.96 \\
\hline 5. & Satchinez I & 6.35 & 56.41 & $-4.90^{00}$ & 61.81 & 320.84 & $42.54 * * *$ & 379.82 & 163.23 & 147.13 \\
\hline 6. & Satchinez II & 6.05 & 53.79 & $-5.20^{00}$ & 49.06 & 254.65 & $29.79 * *$ & 303.16 & 130.28 & 70.47 \\
\hline 7. & Satchinez III & 5.86 & 52.11 & $-5.39^{00}$ & 42.49 & 220.58 & $23.23^{*}$ & 292.39 & 125.65 & 59.70 \\
\hline 8. & Satchinez IV & 5.74 & 51.04 & $-5.51^{00}$ & 56.89 & 295.30 & $37.62 * * *$ & 279.51 & 120.12 & 46.82 \\
\hline 9. & Aldeşti I & 16.28 & 144.69 & $5.03 * *$ & 54.43 & 282.55 & $35.17 * *$ & 931.17 & 400.17 & $\begin{array}{c}698.48 * \\
* *\end{array}$ \\
\hline 10. & Aldeşti II & 8.22 & 73.07 & -3.03 & 55.62 & 288.73 & $36.36 * *$ & 464.78 & 199.74 & $232.09 *$ \\
\hline 11. & Rieni I & 8.10 & 72.01 & -3.15 & 41.06 & 213.13 & $21.79 *$ & 331.79 & 142.59 & 99.10 \\
\hline 12. & Rieni II & 7.22 & 64.19 & $-4.03^{0}$ & 39.78 & 206.48 & $20.51^{*}$ & 288.71 & 124.07 & 56.02 \\
\hline 13. & Rieni III & 17.07 & 151.66 & $5.81 * *$ & 30.30 & 157.28 & 11.03 & 518.39 & 222.78 & $285.70^{*}$ \\
\hline 14. & Apateu I & 13.58 & 120.65 & 2.32 & 28.75 & 149.23 & 9.48 & 388.99 & 167.17 & 156.30 \\
\hline 15. & Apateu II & 10.81 & 96.04 & -0.44 & 47.10 & 244.51 & $27.84 * *$ & 502.79 & 216.07 & $270.10^{*}$ \\
\hline 16. & Pădureni & 9.46 & 84.05 & -1.79 & 38.02 & 197.35 & 18.75 & 356.39 & 153.16 & 123.70 \\
\hline 17. & Secusigiu & 8.90 & 79.12 & -2.35 & 28.71 & 149.05 & 9.45 & 255.97 & 110.00 & 23.28 \\
\hline \multirow[t]{2}{*}{18.} & Juliţa & 11.95 & 106.21 & 0.70 & 30.58 & 158.75 & 11.32 & 361.77 & 155.47 & 129.08 \\
\hline & & \multicolumn{3}{|c|}{$\begin{array}{c}\mathrm{LSD}_{5 \%}=3.38 \mathrm{~g} ; \mathrm{LSD}_{1 \%}=4.65 \mathrm{~g} ; \\
\mathrm{LSD}_{0,1 \%}=6.37 \mathrm{~g}\end{array}$} & \multicolumn{3}{|c|}{$\begin{array}{c}\text { LSD }_{5 \%}=19.61 \mathrm{~g} ; \text { LSD }_{1 \%}=26.95 \\
\mathrm{~g} ; \mathrm{LSD}_{0,1 \%}=36.90 \mathrm{~g}\end{array}$} & \multicolumn{3}{|c|}{$\begin{array}{l}\text { LSD }_{5 \%}=208.46 \mathrm{~g} ; \text { LSD }_{1 \%}= \\
286.51 \mathrm{~g} ; \text { LSD }_{0,1 \%}=392.23 \mathrm{~g}\end{array}$} \\
\hline
\end{tabular}

\section{CONCLUSIONS}

Within the collection, the biggest differences between the populations were for the length of the fruits and their weight, the number of fruits per plant and their weight. Between the two experimental years there are quite large differences in the average values for all characters, which demonstrates the influence of natural conditions. The intrapopulational variability is lower for fruit size and high for the average weight of a fruit, the number and weight of fruit per plant.

The length of the fruits in the collection varied from average values of approximately $5 \mathrm{~cm}$, to average values of over $15 \mathrm{~cm}$. For the diameter of the fruit, there was not much diversity. The statistical processing on the experimental cycle highlights the differences between the populations and the control variety.

The dimensions of the fruits showed the greatest variability, especially the length of the fruit. The longest fruits were reported in the populations of Juliţa, Aldeşti I and Satchinez I. The shortest fruits were present in the population of Satchinez III.

The control variety had large fruits, which is why only the Rieni III population had significantly heavier fruits $(17.07 \mathrm{~g})$. For the number of fruits per plant, most landraces are higher than the Portocaliu variety. For the large number of fruits per plant, the population of Temerești II (89.82 fruits) is recommended, but also the populations of Temerești III and Satchinez I, with over 60 fruits per plant. From the combination of the number of fruits and the weight of a fruit, it appears that both are important for the production of fruit on the plant. Thus, the populations of Aldești I (931.17 g / plant), Rieni II and Apateu II (with over $500 \mathrm{~g} /$ plant) stand out, however, no were reported extreme values for any of the other characters. 
The established and studied collection includes possible genitors or the basis of selection for all the characters involved in plant productivity.

\section{REFERENCES}

Birhanu, Habtie, Tiegist, Dejen, Yigzaw, Dessalegn (2017) Morphological characterization of hot pepper (Capsicum annum L.) landraces of Ethiopia for qualitative characters, International Journal of Research Studies in Science, Engineering and Technology, 4(I9), 4-9.

Ciulca, S. (2006) Metodologii de experimentare în agricultură şi biologie [Experimental methodologies in agriculture and biology], Ed. Agroprint, Timisoara

Derek, W., Barchenger, Clark III, R.A., Gniffke, P.A., Ledesma Dolores, Shih-wen, Lin, Hanson, P., Sanjeet, Kumar (2018) Stability of Yield and Yield Components of Pepper (Capsicum annuum), and Evaluation of Publicly Available Predictive Meteorological Data in East and Southeast Asia, HortScience 31(12), 1776-1783.

Fasikaw, Belay, Berhanu, Abate, Yemane, Tsehaye (2020) Genetic Variability and Characters Association of Hot Pepper (Capsicum annuиm L.) Genotypes Tested under Irrigation in Northern Ethiopia, Agricultural Science 2(1), 289-303.

Kuhn, Massot, Padilha H., Barbieri, Rosa, Lia (2016) Plant breeding ofchili peppers (Capsicum, Solanaceae)-A review, Australian Journal of Basic and Applied Sciences, 10(15), 148-154.

Leonel, V.C., Anderson, Y.S.F., Douglas, M.Z., Yumi, Baba, Viviane, Erpen-Dalla, Corte, Ligia, Mussoi, Giacomin, Renata, Vilela, Resende J.T., Azeredo, Gonçalves, L.S. (2020) Genetic variability in peppers accessions basedon morphological, biochemical and molecular traits, Bragantia 79(4),433-446.

Maaike,Wubs, A., Yun, T.Ma, Heuvelink, Ep, Hemerik, Lia, Marcelis, L.F.M. (2012) Model Selection for Nondestructive Quantification of Fruit Growth in Pepper, Journal of the American Society for Horticultural Science 137(2), 71-79.

Madoşă, E., Ciulca, S., Velicevici, Giancarla, Avădănei, C., Sasu, Lavinia, Şulea, Diana, Cioroga, Adriana (2008) Assessment of some yield components of pepper (Capsicum annuиm L.) local germplasm collected from West part of Romania, Proc. 43 rd Craoatian and 3rd Int.Symp. on Agriculture, 18-21.02.2008, Opatija, Croatia, 380-384.

Madoşă, E., Sasu, Lavinia, Ciulca, S., Velicevici, Giancarla, Ciulca, Elena Adriana, Avădanei, C. (2010) Possibility of use of romanian bell pepper (Capsicum annuum L.var grossum) local landraces in breeding process, Notulae Botanicae Horti Agrobotanici Cluj Napoca, 38 (2) special issue, 56-60.

Maryse, N., Cantet, Meissa, Lefebvre, Veronique, Sage-Palloix, Anne-Marie, Palloix, A. (2013) Genotyping a large collection of pepper (Capsicumspp.)with SSR loci brings new evidence for the wild origin of cultivated C.апnиит and the structuring of geneticdiversity by human selection of cultivar types, Genet Resour Crop Evol 60, 2375-2390.

Meena, M.L., Kumar, N., Meena, J.K., Rai, T. (2016) Genetic variability, heritability and genetic advances in chilli, Capsicum annuum, Biosci. Biotech. Res. Comm. 9(2), 258-262.

Munoz-Concha, D., Quinones, Ximena, Hernandez, J., Romero S.P. (2020) Chili Pepper Landrace Survival and Family Farmersin Central Chile, Agronomy, 10, 1541; doi:10.3390/agronomy10101541.

Orobiyi, L., Loko, Y., Sanoussi, F., Agré, A.P., Korie, N., Gbaguidi, A., Adjatin, A., Agbangla, C., Dansi A. (2017) Agro-morphological characterization of chili pepper landraces (Capsicum annuиm L.) cultivated in Northern Benin, Genetic Resources and Crop Evolution, DOI: 10.1007/s10722-017-0553-x.

Pereira-Dias, L., Vilanova S., Fita, Ana, Prohens J., Rodriguez-Burruezo, A. (2019) Genetic diversity, population structure, and relationships in a collection of pepper (Capsicum spp.) landraces from the Spanish centre of diversity revealed by genotyping-by-sequencing (GBS), Hortic Res. 6: 54, doi: 10.1038/s41438-019-0132-8.

Ramchiary, N., Kehie, Mechuselie, Brahma, Vijaya, Tandon, Pramod (2013) Application of genetics and genomics wards Capsicum translational research, Plant Biotechnol Rep, DOI 10.1007/s11816-013-0306-z.

Shimeles, Aklilu, Bekele, Abebie, Dagne, Wogari, Adeferis, T.Wolde (2016) Genetic variability and association of characters in ethiopian hot pepper (Capsicum annum L.) landraces, Journal of Agricultural Sciences 61(1), 1936.

Zhang, Xiao-min, Zhang, Zheng-hai, Gu, Xiao-zhen, Mao, Sheng-li, Li, Xi-xiang, Chadœuf, J., Palloix, A.,Wang, Lihao, Zhang, Bao-xi (2016) Genetic diversity of pepper (Capsicum spp.) germplasm resources in China reflects selection for cultivar types and spatial distribution, Journal of Integrative Agriculture 15(9), 1991-2001 